\title{
UMA INTERPRETAÇÃO TRANSDISCIPLINAR DO MUNDO SOCIAL
}

\author{
A transdisciplinar interpretation oh the social word \\ Una interpretación transdisciplinaria del mundo social
}

\author{
Paul Claval* \\ *Universidade Sorbonne - p.claval@wanadoo.fr. \\ Tradução: Rosa Maria Veira Medeiros* \\ ** Universidade Federal do Rio Grande do Sul - rmvmedeiros@ufrgs.br.
}

\begin{abstract}
Conteúdo do artigo originalmente apresentado em palestra no $1^{\circ}$ Evento Transversal promovido pelo Projeto das Disciplinas Transversais da UFPR em 09/09/2020.

Versão online publicada em 23/03/2021 (http://seer.ufrgs.br/paraonde)
\end{abstract}

Como citar este artigo: CLAVAI, P. Uma interpretação transdisciplinar do mundo social. Tradução de Rosa Maria Vieira Medeiros. Para Onde!?, v. 15, n. 1, p. 01-18, 2021.

\section{Resumo:}

As ciências do homem e da sociedade diferem nos dados e documentos a partir dos quais elas abordam os fatos sociais e, pelos métodos que utilizam para os explorar, mas todas dizem respeito ao homem enquanto animal social: compartilham a mesma base transdisciplinar. Explora as dimensões ecológicas, técnicas, culturais, econômicas e políticas da vida coletiva. Essa plataforma comum tem sido explorada há muito tempo sob uma perspectiva que enfatizava o peso da economia na vida social: a abordagem era socioeconômica. Os trabalhos atuais focam mais na cultura: a abordagem se torna sociocultural. É sobre ela que vamos insistir.

Palavras-chave: Cultura, abordagem sociocultural, transdisciplinaridade.

\begin{abstract}
:
The sciences of man and society differ in the data and documents from which they approach social facts and, by the methods they use to explore them, but they all concern man as a social animal: they share the same transdisciplinary basis. It explores the ecological, technical, cultural, economic and political dimensions of collective life. This common platform has long been explored from a perspective that emphasized the weight of the economy in social life: the approach was socioeconomic. Current works focus more on culture: the approach becomes sociocultural. It is about it that we will insist.
\end{abstract}

Key-words: Culture, sociocultural approach, transdisciplinarity.

\section{Resumen:}

Las ciencias del hombre y de la sociedad difieren en los datos y documentos a partir de los cuales ellas abordan los hechos sociales $y$, por los métodos que utilizan para explotarlos, pero todas dicen respecto al hombre como animal social: comparten la misma base transdisciplinaria. Explora las dimensiones ecológicas, técnicas, culturales, económicas y políticas de la vida colectiva. Esta plataforma común ha sido explorada durante mucho tiempo desde una perspectiva que enfatizaba el peso de la 
economía en la vida social: el enfoque era socioeconómico. Los trabajos actuales se centran más en la cultura: el abordaje se vuelve sociocultural. Es sobre ella que vamos a insistir.

Palabras-clave: Cultura, enfoque sociocultural, transdisciplinariedad.

\section{Lógicas ecológicas e técnicas}

\subsection{Ecossistemas naturais e ecossistemas antropogênicos}

Como todos os seres vivos, o homem faz parte dos ecossistemas dos quais ele extrai os elementos de origem vegetal ou animal necessários para o desenvolvimento de seus tecidos, para a energia exigida para seus deslocamentos, suas atividades e o funcionamento de seu organismo. Ele igualmente encontra em seu ambiente as fibras que usa para se vestir e os materiais com os quais constrói seus abrigos, fabrica suas ferramentas e constrói suas máquinas.

O homem se insere nos ecossistemas naturais, depois os substituem por outros que fornecem mais alimentos ou matérias-primas, mesmo que sua produtividade total seja geralmente menor do que aquela dos ecossistemas não antropizados.

\subsection{Técnicas e meio ambiente}

O homem age sobre o meio ambiente por gestos. Ele prolonga esses gestos no uso de ferramentas com as quais ele se equipa. Ligando, uns aos outros, os instrumentos assim criados, ele constrói máquinas que encadeiam os movimentos, fazem peças, fiam e tecem fibras, etc. Ligadas mecanicamente por longo tempo, estas sequências são cada vez mais informatizadas. A energia que move as máquinas era na origem, humana ou animal; foi substituída por motores que movimentados por combustíveis fósseis e, em menor grau, naturais ou nucleares. A introdução de ciclos de feedback, regula o funcionamento das máquinas e permite que os robôs realizem operações cada vez mais complexas.

\subsection{As grandes revoluções técnicas e suas consequências ambientais}

Uma série de mutações transforma as relações entre o homem e o meio ambiente. A colheita, a pesca e a caça permitiram aos homens do Paleolítico tirar partido dos ecossistemas naturais. A revolução neolítica substituiu-os por ecossistemas antropizados voltados para a pecuária e a agricultura; os efetivos humanos se multiplicaram; como os rendimentos permaneceram baixos, $80 \%, 90 \%$ ou mais dos trabalhadores permaneceram ligados à terra e povoaram o campo. A revolução industrial mecanizou as atividades de transformação. Na segunda fase, ela revoluciona o trabalho agrícola e desenvolve bens duráveis que transformam a mobilidade individual, perturbam a vida doméstica, diversificam o lazer e multiplicam os consumos diretos do espaço pela prática de esportes ou por atividades culturais. Nos últimos cinquenta anos, a revolução da informática remodela as redes e dá novas formas à comunicação. 
Graças ao progresso das técnicas que mobilizam o homem, as relações que ele estabelece com o meio ambiente não param de evoluir. As energias derivadas do células solares se somam àquelas produzidas pelos combustíveis fósseis. Quantidades cada vez maiores de produtos químicos deliberadamente ou involuntariamente perturbadores foram injetados nos ecossistemas artificiais. Até um certo limite eles retêm a capacidade de restaurar seus equilíbrios dinâmicos: eles permanecem resilientes. Para além disso, deixam de o ser. As liberações de dióxido de carbono, metano e alguns outros gases alteram a composição da atmosfera, acentuam o efeito de estufa sobre todo o planeta e provocam o aquecimento climático.

O homem se encontra assim colocado perante uma nova responsabilidade: a de gerenciar a totalidade do ambiente terrestre de maneira sustentável.

\subsection{Ecologia e ecologismo}

Foi em 1866 que Ernst Haeckel criou uma disciplina nova dedicada às relações dos seres e do meio onde vivem: a ecologia. Ela se desenvolve a partir dos anos de 1890. Estrutura-se dando foco nas cadeias tróficas que ligam os seres vivos e analisando os ciclos de energia e matéria que ocupam lugar na biosfera: o modelo de interpretação que ele implementa é termodinâmico, como mostra o tratado publicado por Edgar Odum¹. Com os avanços da genética, a curiosidade muda para os grupos de genes que compõem os ecossistemas e que testemunham sua biodiversidade. É a esta que eles devem sua resiliência.

A reflexão sobre a ecologia também toma uma forma normativa: aquela da ideologia. Os ecologismos fixam aos homens metas para salvaguardar ou restaurar os ambientes naturais e tornar sustentáveis os modos de exploração que implementam. O mundo não acredita mais no progresso técnico e nas filosofias da história: os ecologismos os substituem; estão no coração das ideologias da pósmodernidade.

Um ramo da geografia, a mesologia, explorando há quarenta anos a maneira na qual os homens se inserem no ambiente, o pensam, o exploram sem escrúpulos ou o gerenciam sabiamente? ${ }^{2}$.

\section{Lógicas ecológicas e técnicas}

Dizer que o homem é um ser social é enfatizar que é da sua natureza viver com outros seres humanos. Isso significa que o homem e a sociedade são realidades tão intimamente entrelaçadas que não se pode conceber um sem o outro. $\mathrm{Na}$ geografia, a mudança cultural que a disciplina começou a tomar por volta de 1970, e da qual se fala desde o final dos anos 1990, completou assim a análise das lógicas socioeconômicas até então favorecidas pela das lógicas socioculturais. As outras disciplinas sofreram mudanças semelhantes, mesmo que tenham sido qualificadas de outra forma: mudança linguística na história ou espacial na sociologia. Em todo caso, a atenção está voltada para o que constitui o DNA dos

1 Odum, E. , 1951, Fundamentos da Ecologia, Filadélfia, Saunders.

2 Veja em particular: Berque, A., Berque, A., 2000, O Ecoumeno. Introdução ao estudo dos ambientes humanos, Paris, Belin. Berque, A., 2018, Glossário da mestologia, Bastia, Wind Edition. 
grupos sociais, sobre os softwares que implementam, sobre sua cultura ${ }^{3}$.

\subsection{A raiz do indivíduo e da sociedade: a comunicação 4}

Para apreender a vida social, a abordagem cultural parte da ideia de que o ser social é fundamentalmente um ser de comunicação: recebe dos outros o que não é inato nele (o essencial de suas capacidades); a partir de um certo momento e em menor grau, ele as desenvolve por ele mesmo. Ele marca, memoriza e interioriza o que ele vê e o que ouve.

A comunicação se baseia na fala e na observação dos gestos de outrem e nas emoções que são lidas em seu rosto. Ela traz consigo práticas, saberes, conhecimentos e crenças, sentimentos estados da alma. Ela chega como uma imagem, um ruído, uma música evocando um evento que todos compartilham: um sinal simples, um símbolo, faz assim vibrar as imensas multidões em uníssono.

A linguagem é dividida em palavras e estas em sinais fonéticos que podem ser transcritos em caracteres ou em letras: assim nasce a escrita.

A comunicação contém um número variável de pessoas; a distância que os separa e mais ou menos importante; a quantidade e a qualidade das informações transmitidas são muito diversas.

$\mathrm{Na}$ sociedade de oralidade, a totalidade disto que recebe o indivíduo lhe é veiculado pelo gesto e pela palavra e provem necessariamente de seu ambiente próximo. A escrita viaja facilmente, ela serve menos à transmissão de gestos, mas convém perfeitamente a tudo isto que se pode exprimir pelas palavras: os conceitos, os conhecimentos, as crenças. Ela dota também cada um e a sociedade no seu conjunto, de memórias objetivas: ela os faz assim entrar na história.

Enquanto a alfabetização dos grupos humanos permanecer limitada, as sociedades justapõem as culturas essencialmente orais de suas classes trabalhadoras com aquelas, baseadas na palavra escrita, de suas elites. Graças à impressão e à educação obrigatória, todos finalmente têm acesso à escrita, mas ao possibilitar transmitir fala e gestos remotamente, novas mídias estão levando a uma transformação das culturas populares, enquanto computadores, celulares e redes sociais estão atrapalhando a transmissão de ideias e a estrutura da opinião pública.

\subsection{Divisão de tarefas, papéis, funcionamento da sociedade e formação de classes}

A abordagem cultural se concentra na vida dos homens e no funcionamento da sociedade: cada um assume, dependendo da hora e do dia, diferentes papéis em diversos sistemas de relações sociais: O Sr. Dupont é, por exemplo, um homem de família do retorno do trabalho, no final da tarde, para o café da manhã na manhã seguinte; no ônibus para a fábrica, ele é cliente de uma empresa de transporte; na oficina onde trabalha como técnico, recebe instruções de um engenheiro e compartilha as tarefas da pequena equipe que mantém e conserta as máquinas. Depois de sair do trabalho, tornou-se cliente das lojas que frequentava, ativista por

3 Claval, P., 2020, A abordagem da bundaturelle, Vayrac, Tertium, online.

4 Ibid. chap. 4.

ParaOnde!?, Porto Alegre, v.15, n.1, p.01-18, 2021. http://seer.ufrgs.br/paraonde 
anos no sindicato ao qual se formou, esportista pelo clube onde fazia ginástica, etc.

Através dos papéis que desempenham nas organizações sociais em que participam, os homens contribuem para o funcionamento da sociedade. Aqueles que ocupam as mesmas posições em organizações sociais do mesmo tipo enfrentam os mesmos problemas e têm os mesmos interesses a defender: formam comunidades potenciais; se unem para defender sua causa quando seus membros podem se comunicar uns com os outros: as comunidades se tornam classes sociais 5 .

A importância que cada pessoa atribui aos seus diversos compromissos na vida social depende de ambas as circunstâncias, sua educação e sua individualidade. Em alguns casos, é a defesa das condições de trabalho e da remuneração que prevalece; em outros, é o pertencimento a um grupo étnico, uma comunidade religiosa ou um partido político que prevalece. A abordagem cultural encontra, assim, como um caso particular, as afiliações de classe às quais a abordagem socioeconômica foi essencialmente anexada.

Quando as relações entre indivíduos são apenas sobre seus problemas pessoais, como amizade, eles permanecem livres. Todos aqueles que envolvem interesses coletivos são, por outro lado, institucionalizados; é a família, sua extensão ao clã ou tribo, a associação, a casta, o relacionamento cliente ou feudal, a empresa ou a administração, a igreja, o sindicato, o partido, etc.

\subsection{Representações, imaginação, normas e instituições sociais}

Os homens não apreendem a realidade, mas as representações que fazem dela e que tomam a forma de discursos ou imagens. Sua inteligência traduz em palavras ou padrões a experiência que eles têm do mundo e as sequências que o caracterizam: ela assim orienta sua ação. Sua imaginação começa com palavras ou imagens para criar os imaginários ${ }^{6}$. Ela o faz em dois níveis: (i) ela recompõe o real, mistura-o com sonhos, poetiza-o; (ii) ela duplica o nosso ambiente de outros mundos que ela inscreve no além do céu, no além das profundezas subterrâneas, ou em lugares terrestres, mas que pessoas não podem visitar porque eles pertencem ao passado enterrado da Idade de Ouro, ao futuro impreciso da Utopia, ou se localizam numa Terra sem Mal proibida aos viajantes. Esses mundos sendo perfeitos, eles permitem, por comparação, julgar o nosso. Eles introduzem 7 , assim, uma ordem normativa que rege o comportamento humano e direciona a ação para regular ou transformar a existência coletiva. O social se apresenta sob dupla forma de uma realidade empírica e de um mundo instituído: ele só se torna de fato verdade depois de ter sido assim recriado.

O além toca o nosso mundo em certos lugares e cria espaços ontologicamente diferentes, as áreas sagradas. Revestindo-se de sacralidade o quadro banal e profano da vida de todos os dias, festas e cerimónias purificam-no, regeneram-no e restituem-lhe o brilho do primeiro dia ou anunciam o Juízo Final.

Michel Foucault prolongou esta análise pondo em evidência aquilo a que

5 Claval, P., 1973, Princípios da geografia social, Paris, M.-Th. Genin.

6 Claval, P., 2020, A Abordagem Cultural, Op. cit., sujeito.

7 Claval, P., 1994, Geografia Cultural, Paris, Nathan. 
chamou heterotopies: ${ }^{8}$ estes lugares são tão diferentes dos espaços profanos da vida quotidiana como o fazem as zonas sagradas, mas situam-se moralmente abaixo dos espaços normais, e não acima: servem para esconder modos de vida e de agir que não podem passar sem o grupo, mas que condenam as regras que ele se dá e a moral que apresenta; trata-se de antimundos da infâmia, da imoralidade ou do desvio.

\subsection{A formação da opinião pública}

A cultura é feita de representações. É interiorizando uma parte do conjunto comum de atitudes, de práticas, de saber-fazer, de conhecimentos e de crenças que ela constitui que a criança se forme e que o homem se torne um ser social.

Numa sociedade, nem todos têm a mesma percepção do ambiente, do grupo, das suas regras e das suas práticas. Quando as pessoas falam disso em encontros, manifestam-se opiniões divergentes sobre os temas abordados; iniciam-se discussões, emerge um certo consenso: forma-se uma opinião pública.

Nas sociedades em que a comunicação se faz oralmente, por ocasião de contatos diretos, face a face, a troca de opiniões é igualitária, mas apenas diz respeito a círculos estreitos. A escrita amplia os raios de troca, mas as relações são geralmente assimétricas, favorecendo a difusão hierárquica da opinião de alguns mais do que o confronto das ideias de todos.

A impressão multiplica o número daqueles que têm acesso à escrita. $O$ estabelecimento de sistemas postais cria círculos de correspondentes entre os quais as opiniões circulam na escala de um país e além. O progresso da edição e da publicação de jornais a um número crescente de pessoas, as opiniões que se trocam, se confrontam e se estruturam nos círculos intelectuais. É o que agora se designa por opinião pública ${ }^{9}$, mas sem sublinhar que funciona a dois níveis: forma-se no seio de um establishment bastante limitado de pessoas instruídas; a imprensa difunde as discussões que aí se realizam; estas inspiram então as escolhas das camadas menos instruídas.

A revolução contemporânea da informática, a difusão do computador, e aquela, mais ampla do telefone celular fazem nascer as redes sociais: as ideias são trocadas em uma base igualitária em espaços enormes; a entrada não é mais reservada àqueles que dominam os códigos de comunicação escrita. Os tempos das opiniões públicas dominadas por um establishment intelectual acabaram ${ }^{10}$. Como era sobre ele que assentava o funcionamento das democracias representativas, os fundamentos da vida política dos países avançados são abalados: as formas contemporâneas da opinião pública dão origem às correntes populistas.

\subsection{Dinâmica sociocultural e competição por status}

8 Foucault, M., 1984, "Des espaces autres (conférence au Cercle d'études architecturales, 14 mars 1967), Architecture, Mouvement, Continuité, n5, octobre, p. 46-49. Repris dans Dits et écrits.

9 Habermas, J., 1978, L'Espace public. Archéologie de la publicité comme dimension constitutive de la société bourgeoise, Paris, Payot ; éd. or., 1962.

10 Claval, P., 2020, A Abordagem Cultural, Op. Cit. chap. 6.

Para0nde!?, Porto Alegre, v.15, n.1, p.01-18, 2021. http://seer.ufrgs.br/paraonde 
Observando seus semelhantes, os indivíduos se tornam conscientes de quem são, do que compartilham com alguns e do que se opõe a outros. Assim se formam os sentimentos de identidade, onde expressam às vezes a convicção de pertencer a um grupo ou aquele de ser um estranho para os outros.

Dentro de um grupo de pertencimento, várias estratégias são abertas aos indivíduos, segundo as circunstâncias e segundo o papel que desejam desempenhar. Às vezes eles sonham em se fundir na massa a ponto de desaparecer completamente. Em outros momentos, eles buscam distinguir-se de seus pares se mostrando mais ${ }^{11}$ respeitosos dos princípios morais, mais corajosos, mais educados, mais alegres ou melhores companheiros... Eles ganham prestígio e o benefício de um certo renome. Eles servem como exemplos. Sua posição se afirma: um status lhes é reconhecido, o que Ihes rende estima, consideração e influência.

Existem várias formas de competição por cargos que permitam emergir do lote comum dentro dos grupos sociais. Elas visam garantir o poder sobre os outros, a riqueza que permite criar um ambiente mais agradável e fazer outros trabalhar em seu benefício, ou um status que simbolicamente o coloca acima de todos os participantes e lhe dá a consideração dos outros. As abordagens socioeconômicas que há muito dominam as ciências sociais se concentraram principalmente na dinâmica resultante da busca pelo poder e pela riqueza, somente são exceções a antropologia e a história antiga, que se dedicavam às sociedades onde era travada a competição política e económica e onde o status dominava.

Como mostrou Norbert Elias, a busca ${ }^{12}$ pelo status pode desencadear um processo de civilização em um conjunto de um grupo ou de uma sociedade: é se mostrando mais corajoso, mais religioso, mais culto, mostrando mais inteligência e sensibilidade, cultivando as artes, letras ou ciências que vão lhe destacar; quando todos entram na corrida, todo o grupo inteiro vai além do que ele realizava até então.

No caso da modernidade, os artistas se distinguem renovando sem cessar os critérios de sua originalidade, o que lhes garante a manutenção de uma posição privilegiada, aquela da vanguarda ${ }^{13}$. As mídias modernas introduzem um outro modo de distinção: aquele da visibilidade ${ }^{14}$ : o importante é agora evoluir nos lugares da moda e participar dos eventos mais populares para atrair a atenção de jornalistas, de fotógrafos ou de cineastas.

As dinâmicas propriamente culturais, há muito reduzidas, contribuem então para modelar as sociedades: elas têm mundos de valores, sejam morais, estéticos ou intelectuais. Às vezes, elas estruturam a sociedade em comunidades ciumentas de sua identidade. Eles dão origem às elites artísticas e intelectuais. Dão ao establishment intelectual das democracias modernas, a responsabilidade de legitimar (ou criticar) as instituições. A busca pelo status não para de assumir novas

11 Bourdieu, P., 1978, A Distinção, Paris, meia-noite.

12 Elias, N., 1939/1969-1976, Sobre o processo da civilização, 2 vol; Juntado. Francês, vol.1, A Civilização de Mores, Paris, Paris, Calmann-Lévy, 1969; Vol. 2., A Dinâmica do Oeste, Paris, Calmann-Lévy, 1976.

13 Heinich, N., 2005, O Artista de Elite. Excelência e singularidade em um sistema democrático, Paris, Gallimard.

14 Heinich, N., 2012, Visibilidade. Excelência e singularidade no sistema de mídia, Paris, Gallimard. 
formas nas sociedades contemporâneas. Esta busca influencia profundamente os processos nascidos da vontade de poder ou da sede de riqueza.

\section{Lógicas econômico-culturais}

A obra propõe uma interpretação mais ampla do capitalismo que enfatiza suas dimensões espaciais.

O capital é uma acumulação que pode ser de saberes e conhecimento (capital humano) e relações sociais (capital social). Ele desempenha um papel na competição entre indivíduos, dando a alguns uma vantagem sobre outros. Ele se desenvolve quando a troca toma uma forma monetária e se reveste, em primeiro lugar, em uma forma comercial: está fazendo um desvio espacial, indo buscar longe produtos cobiçados que lhe trazem fortuna. O desvio torna-se productif com a revolução industrial, que confere uma vantagem para aqueles que investem em equipamentos e máquinas capazes de substituir a força dos braços graças à energia proporcionada pelos motores. O desvio torna-se financeiro quando permite coletar as economias das pessoas, ou criar dinheiro, para fazer investimentos. O desvio torna-se informático quando implementa novas tecnologias para estruturar por novas redes, a vida de relacionamento das sociedades.

Essa interpretação do capitalismo encontra os pontos essenciais da interpretação marxista, mas difere em dois pontos: a vantagem que é fonte de lucros vem do desvio que permite mobilizar novas forças atuando sobre a mobilidade, a organização das operações produtivas, os circuitos monetários ou redes de informação; ele paga uma renda temporária de escassez, mais do que o resultado de uma forma de exploração ou extorsão. Controlar os excessos não envolve necessariamente uma luta; isso pode resultar da realização de solidariedade.

Essa interpretação é particularmente útil para compreender o capitalismo contemporâneo.

\subsection{Busca por riqueza e desvio produtivo ${ }^{15}$}

A economia se liga aos bens raros porque a natureza é mesquinha ou envolve trabalho longo e delicado. As riquezas nascem tanto da natureza (o fator terra) e do esforço que é necessário tomar para produzi-los (o fator trabalho). O agente que procura enriquecer ganha em não se lançar na empresa sem pensar: descobre assim que se tornará mais eficaz acumulando previamente saberes e conhecimentos - um capital humano - e dotando-se de melhores ferramentas - bens capitais. Faz assim um desvio que lhe confere capacidades superiores. O desvio pode fazer-se através da violência: a economia é predatória quando se baseia na pilhagem do que é produzido por outros; é escravagista quando se baseia no trabalho forçado de adversários feitos prisioneiros ou privados dos seus direitos humanos.

15 Claval, P., 2020, O desvio capitalista, Vayrac, Tertium, online. 


\subsection{Da autarquia às trocas: a autonomização da economia}

Toda a vida social envolve a produção de alimentos para se alimentar, ferramentas para atuar de forma eficaz, matérias-primas para fazer roupas, sapatos, casas, objetos domésticos, etc. O ciclo se organiza dessa forma, que vai da produção ao consumo passando por uma fase de distribuição. Nas sociedades que não praticam as trocas, são muitas vezes as mesmas células que produzem e que consomem: falamos de autarquias familiares ou locais. A parte do ciclo dedicada à distribuição das riquezas é escamoteada. Como resultado, o circuito econômico não se diferencia do da vida familiar ou da vida local. Ele não está institucionalizado.

Tudo muda com a invenção do dinheiro. Cada produção respondia a uma finalidade particular: o cultivo de trigo era para a produção de farinha e de pão; a lã obtida pela tosquia das ovelhas destinava-se à confecção de roupas quentes; a fabricação de tijolos servia para a construção de casas. Com o dinheiro, as finalidades particulares cedem lugar a uma finalidade geral: fazer dinheiro, que é então usado para este ou aquele fim específico. O circuito econômico torna-se autônomo; ele se institucionaliza, o que leva à emergência da empresa, por um lado, e na introdução de uma articulação, o mercado, que coloca em relação produtores e consumidores em um quadro competitivo.

A implantação desse sistema se efetua por etapas: os altos custos de transporte limitam inicialmente a extensão das rotas de mercadorias; por via terrestre, eles raramente excedem alguns quilômetros ou algumas dezenas de quilômetros; eles são muito mais longos pela água; os bens de preços ponderados viajam menos longe do que bens de luxo. As atividades econômicas específicas, portanto, dizem respeito, em primeiro lugar, às produções de qualidade; eles prosperam muito mais às margens ou ao longo dos rios.

\subsection{O desvio capitalista}

O capital é o resultado da busca competitiva por riqueza. Baseia-se em um desvio no espaço e/ou na durabilidade; esse processo evolui com o tempo e com as técnicas. Ele chegou à divisão do trabalho e à especialização de cada um ou de cada espaço no qual ele dispunha a maior vantagem comparativa.

É o desvio pela formação que constitui a primeira etapa dessa evolução; ele dota cada indivíduo de um capital humano de saberes e de conhecimento no domínio produtivo, bem como nas técnicas de vida de relações - neste caso, falamos de capital social. Após ver seu papel diminuir durante as primeiras fases da revolução industrial, o capital humano voltou à vanguarda: é preciso muita matéria cinzenta para inventar e desenvolver um novo produto, mas a reprodução do modelo é então feita a custos decrescentes: é uma das fontes de lucro desde que a produção de bens duráveis se desenvolve.

Entre o momento em que o pesquisador grita 'Eureka' porque descobriu, numa espécie de iluminação, o que vai criar, e o momento em que a inovação é desenvolvida, o processo é longo e caro. Ele vai diferentemente à seguinte fase:

Por outro lado, uma vez que esses passos foram dados, se a ideia é aceita, o produto que resulta pode ser multiplicado a um custo muito menor (por isso o primeiro disco compacto, o primeiro computador exigiu esforços colossais por parte daqueles que os desenvolveram, porém sua reprodução

Para0nde!?, Porto Alegre, v.15, n.1, p.01-18, 2021. http://seer.ufrgs.br/paraonde 
de forma idêntica foi muito mais fácil).

A singularidade das ideias que causam mudanças técnicas é que, uma vez que inauguradas, elas dão origem a rendimentos crescentes (as cópias seguintes custam muito menos), mesmo crescendo de forma acentuada (duplicação de software) (DIEMER, s.d., p. 6). ${ }^{16}$

A segunda etapa resulta do progresso da navegação: ir comprar bens onde são abundantes e revendê-los onde são raros e cobiçados paga muito: o primeiro grande capitalismo é comercial e se baseia na exploração de um desvio espacial: os lucros vão para aqueles que são informados das condições da troca em lugares distantes.

A terceira etapa nasce da revolução industrial: ao imaginar máquinas que aumentam a eficiência do trabalho, e motores que substituem a energia humana para executá-los, aumenta-se a produtividade do trabalho a tal ponto que 0 artesanato desaparece.

Quarto passo: o desvio produtivo do capitalismo industrial é acompanhado por desvios espaciais que afetam tanto o que acontece à montante quanto à jusante das cadeias produtivas: à montante, o desvio financeiro drena as economias a curto prazo até então ociosas para os depósitos nos bancos e para a satisfação das necessidades do caixa das empresas, ou para as bolsas de negociação e mercados de câmbio; as economias de longo prazo são coletadas pelos bancos de investimento e bolsas de valores para financiar o investimento das empresas produtoras. À jusante, o desvio para os bens de capital e de consumo durável, da segunda fase da revolução industrial, mecaniza a produção agrícola, revoluciona a mobilidade individual e transforma as tarefas domésticas.

A estrutura do espaço se transforma: facilitando as relações no trabalho no sistema produtivo, o arcabouço urbano gera economias de escalas: aparece assim como uma das molas essenciais de toda a dinâmica econômica do capitalismo: "a cidade é uma espécie de bem comum com múltiplas dimensões, ou um conjunto comum de recursos e sinergias"17.

Presente desde o início da revolução industrial, as vantagens da aglomeração oferecidas pelas cidades revestem assim, uma significação ainda maior no capitalismo cognitivo-cultural: "Os benefícios da aglomeração são reforçados pelo papel da cidade como um lugar de criatividade, de aprendizado e de efeitos de inovação"18 .

Quinta etapa: a revolução informática, que corresponde à última grande onda de inovação no mundo moderno cria novas fabricações e, assim, abre um novo campo para o capitalismo industrial. Ele oferece sobretudo à vida de relação novas redes indefinidamente expansíveis e cujo acesso é fácil - desvio espacial maior, que coloca em questão a organização socioespacial de nossas sociedades.

16 DIEMER, A., S.D., "Crescimento endógeno e convergência", para visitar o site: http://www.oeconomia.net/private/cours/croissanceendogene.pdf, Cf. p. 6.

17 Scott, A.J., 2012, Um Mundo em Emergência. Cidades e Regiões do Século XXI, Cheltenham, Edward Elgar,, p. 24.

18 Ibid. p. 21. 
O dinamismo do capitalismo flexível é incompreensível se ignora-se que o desempenho das combinações baseadas na difusão das inovações intelectuais e na da comunicação está aumentando:

Ao contrário dessas ideias [aquelas de rendimentos constantes qualquer que seja a escala e aquela da concorrência perfeita], a nova teoria de trocas e a nova geografia econômica desenvolvida pelos pesquisadores após a década de 1980 reconhecem todos os dois que hoje, a ordem econômica é mais tipicamente caracterizada pelo aumento dos rendimentos quando a escala aumenta (ver Krugman; Scott ${ }^{19}$ 20; Storper ${ }^{21}{ }^{22}$ ).

Scott disse:

\begin{abstract}
O capitalismo mudou drasticamente desde o fim da alta era do Fordismo, na década de 1970, porque enquanto ainda depende fortemente das tecnologias eletromecânicas e do trabalho manual que caracterizaram essa época, ele é cada vez mais caracterizado por processos de produção controlados por computador e pela proliferação que Ihes é associada, de capital humano altamente qualificado. E resulta que o sistema capitalista está hoje mais dependente do que nunca de uma força de trabalho cujos talentos cognitivos e culturais são finamente aperfeiçoados ${ }^{23}$.
\end{abstract}

Entramos no mundo da economia criativa e cultural:"A economia cognitivocultural pode ser amplamente representada [...] por três grupos ou conjuntos de setores, ou seja, indústria de alta tecnologia, serviços financeiros e empresariais, e a economia criativa ou cultural"24.

A estratificação gerada pela nova economia envolve, portanto, técnicos altamente qualificados e analistas simbolistas, que projetam novos produtos e novos meios de promoção de mercadorias; em relação a eles, desenvolvem-se setores de trabalhadores com salários baixos e muitas vezes orientados para os serviços. Uma nova estrutura de classe se desenha assim.

\title{
3.4 Economia, poder e cultura
}

Dizer que o circuito econômico se autonomizou não significa que ele seja cortado dos jogos de poder e cultura. A abordagem socioeconômica já sublinhava isso: as empresas pesavam o poder pelo lobby, que ela mantinha e que visava reduzir suas cargas tributárias e evitar a introdução de normas técnicas excessivamente restritivas. Eles intervieram em processos eleitorais financiando partidos políticos. Eles influenciaram a opinião pública ao assumir o controle dos órgãos de notícias ou estações de rádio ou televisão. Eles manipularam a demanda através da publicidade.

A novidade nessa área é a liberdade diante do poder público que assegura às empresas as novas tecnologias de transportes rápidos, da comunicação e da informação: se os Estados se mostram muito gananciosos ou muito diretos, as

19 Krugman, P.R., 1991, Geografia e Comércio, Louvain (Leuven), Leuven University Press.

20 Scott, A.J., 2008, Economia Social da Metrópole : Capitalismo Cognitivo-Cultural e o Ressurgimento das Cidades, Oxford, Oxford University Press.

21 Storper, M. 1997, O Mundo Regional : Desenvolvimento Territorial em uma Economia Global, Nova lorque, Guilford Press.

22 Scott, A.J., 2012, Um Mundo em Emergência Op.cit., p. 49.

23 Ibid. P. X.

24 Ibid. p. 41.

Para0nde!?, Porto Alegre, v.15, n.1, p.01-18, 2021. http://seer.ufrgs.br/paraonde 
empresas realocam sua produção para o exterior e instalam sua sede social ou seus serviços importantes em uma cidade global muitas vezes localizada em uma cidadeestado em contato com os paraísos fiscais: elas são assim capazes de "otimizar sua carga tributária", ou seja, de não pagar impostos nos Estados onde elas deveriam fazer.

As relações da economia e do mundo cultural também se transformam. 0 patrocínio continua a desempenhar um papel importante na vida artística, mas o aumento do preço das obras de arte testemunha uma transformação importante: os mercados em que se trocam já não estão separados dos do resto da economia; já não são frequentados apenas por amadores mais ou menos abastados. Os fundos de cobertura de risco operam como em todos os outros mercados.

Ao mesmo tempo, a preocupação de satisfazer uma clientela cujos gostos se diferenciam levam as empresas a aplicar na moda, a incorporar os últimos ditames no design dos seus produtos e a investir na produção artística. Entramos na era do capitalismo cognitivo e cultural ${ }^{25}$.

Como se sabe há muito tempo, a demanda não é determinada apenas pela necessidade. Ela também é pela busca de status: é ela que justifica as navegações dos Argonautas do Pacífico ocidental em busca do bem de prestígio que constitui a kula ${ }^{26}$; é o prazer de se afirmar através do consumo ostensivo que motiva o frenesi de gastos da classe de lazer que Tornstein Veblen analisa no final do século XIX ${ }^{27}$. Cinquenta anos depois, o capitalismo em massa é estimulado por "buscadores de status", que estão constantemente renovando seus produtos de consumo sustentáveis para afirmar seu sucesso ${ }^{28}$. Isso porque a sede por um status construído sobre a visibilidade nunca foi maior do que o capitalismo atual é cognitiva e cultural29.

\section{Conclusão}

A história do circuito econômico uma vez autônoma (uma história que coincide em grande parte com a do capitalismo) destaca um ponto: a vantagem que gera o lucro proveniente de desvios que permitem mobilizar novas forças sobre a

25 Flórida, R., 2002, A Ascensão da Classe Criativa, Nova lorque, Livro Básico. Scott, A.J., 2008, Economia Social da Metrópole: Capitalismo Cognitivo-Cultural e o Ressurgimento das Cidades, Oxford, Oxford University Press. Scott, A.J., 2012, Um Mundo em Emergência. Cidades e Regiões nas 21St Século Cheltenham, Edward Elgar.

26 O kula é uma forma de troca e tem um caráter intertribal bastante amplo: é praticado por comunidades localizadas num extenso círculo de ilhas que formam um circuito fechado(...) Ao longo dessa rota, artigos de dois tipos - e somente desses dois - viajam constantemente em direções opostas. No sentido horário, movem-se os longos colares feitos de contas vermelhas chamados de soulava. No sentido oposto, movem-se braceletes mwali feitos de conchas branca.(...)Cada movimento dos artigos do Kula, cada detalhe das transações é fixado e regulado por uma série de convenções tradicionais; alguns dos atos do Kula são acompanhados de elaboradas cerimônias públicas e rituais mágicos. Malinowski, B., Os West Pacific Argonauts, Paris, Gallimard; ouro ed., 1922.

27 Veblen, Thorstein, 1899, A Teoria da Classe de Lazer, Cidade de Nova lorque Reed., Nova lorque, A Biblioteca Moderna, 1934.

28 Packard V., 1960, O Obcecado em ficar de pé, Paris, Calmann-Lévy; ouro ed. Sou. Os Buscadores de Status, 1959.

29 Scott, A.J., 2012, Um Mundo em Emergência Op. Cit. 
mobilidade, a organização das operações produtivas, a estruturação de circuitos de coleta de dinheiro ou de novas redes de comunicação; o dinheiro ganho paga uma renda temporária de escassez. Para os empresários, a tentação é permanente para garantir uma posição de monopólio para fazer durar esta raridade.

Controlar os excessos do capitalismo requer compreender sua dinâmica.

\section{Lógicas políticas e culturais}

\subsection{Poder, violência e legitimidade}

O poder tem duas fontes: o uso da força e da violência estabelece relações de dominação e faz com que outros ajam sob coação; a autoridade que legitima a tradição, a razão ou o carisma de um líder leva as pessoas a confiar no chefe e seguir suas ordens. A ameaça e o medo multiplicam os efeitos da força. A confiança faz o mesmo com a autoridade.

A obediência que nasce do constrangimento cessa a partir do momento em que os sujeitos já não se sentem vigiados e a ameaça que ela faz pesar sobre eles se dissipa: implica pesadas despesas de controle. Onde a autoridade é reconhecida, a obediência é natural: os custos de exercício do poder diminuem. Uma vez que, numa população, existe uma certa proporção de indolências e de insucessos, os sistemas políticos assentam simultaneamente na legitimidade da sua autoridade e no recurso à violência ${ }^{30}$.

\subsection{Estado e empoderamento da política}

O Estado traz segurança, uma sociedade mais bem organizada, um espaço mais bem organizado, mas reduz a liberdade de um grande número de pessoas e impõe a todos o pagamento de tributos ou de impostos. Sobrepõe-se à sociedade propriamente dita - aquilo a que os politólogos chamam a sociedade civil - a pesada superestrutura de um sistema político, de um Estado. Não é de admirar que as sociedades primitivas tenham sido quase sempre, segundo a expressão de Pierre Clastres, "sociedades contra o Estado"31. Foi necessária toda uma série de circunstâncias para que se tornasse possível a expressão institucional da política e a sua organização ${ }^{32}$.

O Estado constrói-se dotando-se de uma administração (um tipo especial de rede institucionalizada) que assegura a vigilância dos homens e dos territórios, leva as leis ao conhecimento de todos e faz com que sejam aplicadas: em sentido inverso, encaminha para o poder central as informações que recolhe e que requer a elaboração das decisões. Nos sistemas democráticos em que a autoridade provém do povo, o Estado também cria um sistema representativo que permite que a vontade popular se exprima através de eleições. O seu bom funcionamento assenta numa terceira rede, aquela em que se desenvolve a opinião pública. Nos regimes revolucionários, onde a legitimidade nasce de um movimento social, o Partido Único

30 Weber, M., 1971, Economia e sociedade, Paris, Plon; ouro ed. Alemão, Tubingen, 1921-1922. Claval, P., 1979, Espaço e poder, Paris, PUF.

31 Clastres, P., 1974, A Sociedade Contra o Estado, Paris, Edições da Meia-Noite.

32 Cara, M., 1986, As Fontes do Poder Social, Vol. 1, Uma História do Poder do Início ao A.D. 1760, Cambridge, Cambridge University Press. 
substitui a administração e o regime representativo como articulação entre o Poder e o povo em marcha.

\subsection{O Estado Westphaliano e o Estado-Nação}

No mundo ocidental, a autonomização do sistema político torna-se completa no Renascimento. Isto deve-se à evolução do pensamento político: na tradição cristã, o poder que os monarcas detêm é legítimo porque lhes foi delegado por Deus. Os juristas dos séculos XV e XVI deduzem daí que a autoridade que assim receberam não pode deixar de ser absoluta. Maquiavel tira daí as consequências: o Príncipe não tem que prestar contas das suas escolhas a nenhuma autoridade moral que o ultrapasse - a da lgreja em particular; pode, para governar, mobilizar à sua vontade todos os meios e todas as astúcias. É deste estado de fato que tomam nota os Tratados de Vestefália que, em 1648, põe fim à guerra de 30 anos: é por isso que se qualificam de Estados Westphalianos as entidades políticas que gozam de uma soberania absoluta sobre o seu território.

A Reforma divide a Cristandade. Os protestantes insurgem-se contra os soberanos que proíbem aos seus súbditos praticar a religião que a sua consciência Ihes impõe. Os reis devem realmente a sua legitimidade à delegação que receberam de Deus? Não, respondem um certo número de filósofos e de ensaístas: herdaramna do povo, ideia que retomam à velha teoria do contrato social. Esta dá lugar a três interpretações: para Thomas Hobbes, o pacto faz entrar a humanidade na história: até então, o homem era um lobo para o homem. Para escapar a esta terrível situação, os indivíduos renunciam a recorrer à violência e delegam a totalidade dos poderes que detinham no Leviatã, no Estado: a vontade popular legitima assim o poder absoluto. Para John Locke, a assinatura do contrato acontece um pouco mais tarde: através do seu trabalho, as pessoas tornaram-se proprietárias das parcelas de natureza que limparam e valorizaram. Os seus títulos são inalienáveis. O poder que se delega deve respeitar os direitos adquiridos de cada um: é, portanto, limitado. Para Jean-Jacques Rousseau, o pacto intervém também quando a história já começou e a propriedade foi instaurada, mas esta fez perder aos homens a sua inocência. Só a vontade geral do povo pode restaurá-la.

Para Hobbes e para Locke, o povo que delega os direitos que detinha é formado pelo grupo natural que constitui a nação. O Estado westfálico transforma-se num Estado-nação, governado por um déspota esclarecido que exerce um poder absoluto no interesse de todos segundo a interpretação passageira, ou pelo próprio povo e seus representantes na versão Lockiana. Na perspectiva de Rousseau, a vontade geral do movimento revolucionário (que não se enraíza numa longa história) exprime-se num Partido único que age ditatorialmente em nome de uma verdade social a ser posta em prática para assegurar a felicidade de todos.

Três famílias de Estados convivem, portanto, na tradição ocidental desde o século XVIII: (i) o despotismo (ou o autoritarismo) iluminado, que realiza a felicidade do povo graças à ação racional que ele conduz; (ii) a democracia representativa, que leva o povo a construir o seu próprio êxtase e pressupõe uma tripla relação entre sistema político e sociedade civil: um sistema representativo que legitima e limita o poder, uma opinião pública formulada por um establishment intelectual e que permite ao povo formular as suas escolhas, e uma administração que põe em prática

Para0nde!?, Porto Alegre, v.15, n.1, p.01-18, 2021. http://seer.ufrgs.br/paraonde 
as decisões legislativas; (iii) o totalitarismo democrático, cujo Partido Único permite ao povo revolucionário realizar a vontade geral.

A ocidentalização difundiu estes três tipos de formações estatais em todo 0 planeta até aos anos 1950 ou 1960. Hoje em dia, estão em concorrência com outras formas de construção política. A revolução dos meios de comunicação social mina a autoridade do establishment intelectual, que desempenhou um papel essencial no funcionamento dos regimes representativos, enfraquecendo-os. Entrou-se na era da pós-verdade. As democracias surfam sobre esta onda de questionamento da inteligência e sobre os populismos. Uma forma de aliança entre a economia competitiva e o centralismo estatal combina, na China, tradição confucionista e marxismo.

\subsection{A política de Estado e a economia}

O sistema político custa caro para manter: o sistema representativo, o executivo e as administrações empregam multidões de funcionários. A ordem interna se assenta em serviços de polícia e de justiça, na segurança externa, em exércitos. A vida econômica implica a criação de infraestruturas de transporte e de comunicação. Para educar os jovens e proteger os idosos, para assegurar cuidados médicos e pensões a todos e para lutar contra as desigualdades, o Estado de bemestar procede a transferências sociais consideráveis.

A articulação entre o sistema político e a sociedade civil se assenta nos impostos e taxas que o Estado cobra para financiar os seus serviços, equipar o país e assegurar a todos os cidadãos uma vida decente. O levantamento destas contribuições só se torna fácil a partir do momento em que a economia é monetarizada. No mundo tradicional, o poder central tem pouco poder sobre as zonas onde dominam as autarquias familiares ou locais - a maior parte do país durante muito tempo. O imposto só entra bem nas zonas onde a troca se faz a mais longa distância graças à via d'água: trata-se das regiões litorâneas e de uma faixa de alguns quilômetros de largura ao longo dos cursos de água e dos canais. Os direitos aduaneiros pagos pelas importações (e, por vezes, pelas exportações) constituem um dos recursos essenciais dos Estados pré-industriais - o que explica a atenção que dedicam às suas relações externas e às suas políticas de expansão ultramarina. A situação muda quando os fabricantes se multiplicam e as redes ferroviárias alargam as áreas onde circulam os bens. O alargamento da gama dos artigos fabricados aos produtos de consumo sustentável intensifica as trocas - e as riquezas tributáveis.

As economias da maior parte dos Estados do final do século XIX e da primeira metade do século XX são territoriais: muitos circuitos econômicos estão na dimensão do país, de tal forma que dois terços a nove décimos dos seus rendimentos são produzidos e gastos no seu seio ${ }^{33}$. Estes países exportam algumas das suas produções. Faz-se uma diferenciação entre eles. A parte dos artigos fabricados continua a ser importante nas vendas dos países industrializados, a dos produtos primários, no resto do mundo. Caso excepcional: o Reino Unido obtém

33 Claval, P., 1968, Regiões, nações, espaços abertos. Geografia geral de conjuntos territoriais, Paris, M.-Th. Genin.

Para0nde!?, Porto Alegre, v.15, n.1, p.01-18, 2021. http://seer.ufrgs.br/paraonde 
cerca de metade dos seus recursos dos serviços de transporte, de seguros e de organização dos fluxos comerciais e financeiros internacionais que a City de Londres presta ao resto do mundo. Permanecendo ativos até ao século XVIII, os outros Estados comerciais, muitas vezes cidades-Estados, desapareceram face à concorrência de Estados mais vastos.

O novo ritmo da globalização a partir de 1970 e o liberalismo económico que domina a partir dos anos 80 conduzem a uma diversificação rápida das bases económicas dos Estados, cada um que se especialize no setor onde possui a maior vantagem comparativa. A desindustrialização atinge muitas economias territoriais, 0 que obriga uma parte destas a reconverter-se.

As grandes empresas internacionais estão dispostas a instalar as suas sedes sociais ou os seus serviços de direção em cidades globais onde encontram condições ideais para conduzir estratégias à escala mundial. Algumas destas grandes metrópoles situam-se em cidades-Estados, como Singapura ou Hong Kong; outras encontram-se alojadas em economias que permanecem largamente territoriais, como Nova Iorque, Tóquio, Xangai, Londres, Paris ou Amsterdã. As políticas económicas são muitas vezes significativamente influenciadas por elas.

Pequenos Estados estavam a negociar a sua soberania e a transformar-se em paraísos fiscais, onde as empresas declaram rendimentos obtidos noutro lado para beneficiarem de impostos muito mais baixos.

A maior mobilidade dos homens e, a circulação mais rápida e menos onerosa das informações, permitem a alguns países viver dos serviços que prestam aos estrangeiros que os visitam como turistas, que aí se instalem para a reforma ou aí efetuem teletrabalho em benefício de empresas do seu país de origem. Aos rendimentos assim pagos pelos estrangeiros, juntam-se os que são enviados às suas famílias pelos trabalhadores nacionais expatriados. Diz-se hoje que as economias destes países são presenciais ou residenciais ${ }^{34}$.

As relações internacionais ainda não se adaptaram a estas novas condições: foram feitas para um mundo em que todos os países se baseavam em economias territoriais. Já não é o caso.

As empresas internacionais aproveitam as facilidades que lhes oferecem as cidades-Estados e os paraísos fiscais para desviar em seu proveito uma boa parte das somas que deveriam reverter para os Estados nacionais, comprometendo assim as políticas sociais que conduziam, o que aumenta as desigualdades.

Apesar da liberalização da sua economia, o Estado chinês mantém um maior controle sobre as suas empresas do que nos países ocidentais. Ele usa suas empresas para penetrar nas economias de países estrangeiros e conduzir uma política de poder por essa via indireta.

Às práticas milenárias da espionagem, as revoluções técnicas modernas acrescentaram novas possibilidades de interferir na vida dos países estrangeiros: vigilância por radares, satélites, aviões estratosféricos ou drones, ou pirataria informática. Alguns países recorrem amplamente a estes meios para reforçar a sua

34 Davezies, L. 2008. A República e seus territórios. A circulação invisível da riqueza. Paris, Seuil. Davezies L., 2015, Le Nouvel Selfishness territorial, Paris, Seuil.

Para0nde!?, Porto Alegre, v.15, n.1, p.01-18, 2021. http://seer.ufrgs.br/paraonde 
influência - a Rússia de Putin, por exemplo, mas em grande medida a China, assim como os Estados Unidos.

\section{Considerações Finais}

A junção à perspectiva socioeconómica há muito predominante de uma perspectiva sociocultural alarga consideravelmente a compreensão que temos do mundo social e das suas dinâmicas. Ao conceder às afirmações identitárias, à busca do status e à busca da distinção de todo o lugar que lhes pertence, ela faz compreender alguns dos traços característicos do mundo contemporâneo. Ao insistir nas novas ligações que existem entre a economia e o mundo político, ela põe em evidência as novas vias que a procura de poder - e as ameaças que ela faz pesar sobre o mundo atual.

A concepção da ciência e do papel do pesquisador evoluiu. Segundo os positivistas, o sábio lia nos fatos observados a ordem que lá estava contida. Para Kant, o espírito humano era dotado de estruturas a priori que lhe permitiam dar conta das observações empíricas. Segundo Hegel, o filósofo sabia reconstituir, por detrás dos ardis da Razão, a marcha do Espírito. Em Marx, era a evolução do mundo material que revelava a evidência da exploração capitalista. Em todos estes casos, o sábio distinguia-se do comum dos mortais pela mutação de que tinha sido beneficiado os seus modos de pensar - uma revolução copernicana, dizia Kant.

O pesquisador de hoje mostra-se preocupado em não deixar passar nada do que ele pode ver - ele pratica a descrição profunda à maneira de Clifford Geertz. Nunca subestima a inteligência daqueles que estuda e a complexidade e profundidade das suas interpretações. Ele já não tem acesso privilegiado à razão. Graças à profissão que aprendeu, é capaz de analisar a forma como as pessoas concebem os seus saberes e os põem em prática, mas também eles adquiriram uma profissão e formas específicas de apreender o real e de agir sobre ele. A razão não nasce de uma súbita iluminação. Trata-se de uma construção coletiva conduzida paralelamente por todos os que trabalham e pensam. A perícia do pesquisador em ciências sociais não lhe dá o direito de refutar a priori o que pensam e dizem as pessoas que observa, e de subestimar a inteligência daqueles que estuda, assim como a complexidade e profundidade das suas interpretações. Uma ruptura ocorre assim com as epistemologias positivistas, kantianas e hegelianas. A disciplina que se elabora assim é mais modesta, mas como está sempre em busca da verdade, é uma ciência.

Essa abordagem leva a múltiplos resultados:

A - As atitudes e comportamentos dos homens dependem (i) dos modos de comunicação (oralidade, escrita, mídia moderna) utilizados para treiná-los, (ii) dos materiais de memorização aos quais têm acesso e (iii) das técnicas sociais desenvolvidas para disseminar informações. Numa mesma sociedade, nem todos dominam os mesmos meios, nem participam igualmente na mesma cultura, ou pertencem a outra.

B - As decisões são tomadas não em função do real, mas em função das representações que as pessoas fazem delas e que incidem sobre o real ou o transformam em imaginários. Estes transfiguram o real e o poético, ou incidem sobre as margens ou abaixo do mundo (são transcendentes ou imanentes). Criam uma

ParaOnde!?, Porto Alegre, v.15, n.1, p.01-18, 2021. http://seer.ufrgs.br/paraonde 
ordem simbólica e moral, uma ordem sagrada. Os homens recriam e instituem o cosmos, o espaço, a sociedade e o próprio indivíduo, impondo-Ihes esta ordem simbólica.

C - As relações que os homens mantêm colocam-se sob o signo da competição ou sob o signo da cooperação. A competição nasce da busca do poder e do domínio político, da busca da riqueza e do poder de compra ou da procura do capital simbólico e do estatuto. As atitudes de cooperação conduzem à partilha de tarefas. Quando reina a confiança, podem conduzir à delegação das decisões a uma entidade coletiva, que beneficia assim de legitimidade.

Esta leitura da sociedade faz compreender a marca da cultura na organização do espaço, o papel dos sentimentos de identidade e o lugar das religiões e das ideologias. Esclarecem-se as dinâmicas abertas pela busca da distinção e da visibilidade nas sociedades contemporâneas. 